\title{
Avoiding large tailings dams without going underground-Robinsky's thickened tailings concept
}

Tim Fitton Fitton Tailings Consultants, Australia

\section{Abstract}

With the recent high profile failures of the Samarco and Mount Polley tailings dams, governments, environmental groups and mining companies have been looking to alternative methods of tailings storage that are not so reliant on the integrity of large embankment structures.

Underground backfill of tailings is an attractive option at first glance, but unfortunately only a partial solution at the best of times; a typical underground mine can only contain a portion of the tailings whilst mining operations are ongoing, whilst a typical open-cut mine has no underground workings to fill.

Dry stacking of filtered tailings is another attractive option, but it is relatively expensive in most situations. It is also still developing as a technology, with few large scale operations currently in service.

Eli Robinsky's concept for the surface deposition of thickened tailings is a proven technology with dozens of examples of successful implementation around the world. It is asserted that Robinsky's thickened tailings concept has been unfairly ignored or dismissed in some parts of the world, resulting in the ongoing construction of many large tailings dams, all of which increase the risk of another major tailings dam failure occurring in future.

This paper describes Eli Robinsky's concepts of Central Thickened Discharge and Down Valley Discharge, and presents some examples that demonstrate how these tailings storage concepts have been successfully applied in dozens of mines around the world. Some indication of the relative disposal cost per tonne for a number of alternative tailings disposal techniques is also presented.

\section{Introduction}

In recent years tailings dam failures have received significant attention in the media, particularly after the loss of life and environmental damage caused by the catastrophic failures of the Samarco dam in Brazil in 2015 and the Mount Polley dam in Canada in 2014.

In 2016 it was estimated that China had some 153,000 operating mines (Wu, 2016). With so many mines, it is hardly surprising that China has also experienced tailings dam failures. The worst in recent years occurred in the Shanxi province in 2008, where 277 people were killed in the disaster. These dam failures have led the Chinese Government to take a more proactive stance on tailings disposal in the country. Desiring a safer alternative to the conventional dammed surface disposal of tailings, the Chinese Ministry of Finance introduced a 50\% tax exemption for mining companies disposing of their tailings underground.

Since then, numerous Chinese mines have set up underground backfill systems for their tailings, with a few of these thickening the backfill to a paste. Of those few, the HLZM Yunnan mine has installed an underground paste backfill system with a reported maximum capacity of $1,264 \mathrm{~m}^{3}$ per day $(\mathrm{Wu}, 2016)$. However, it is noted that the mine is reported to be one of the largest poly-metallic mines in the world. This would therefore suggest that the backfill system is only handling a very minor fraction of the total tailings production 
from the mine. A large above-ground tailings storage facility must be receiving the vast majority of the tailings.

Generally with underground mines it is not possible to dispose of all of the tailings underground, as the ongoing development of the mine prevents many sections of the underground workings from being available for backfill. It is therefore typically necessary to have a surface tailings disposal running simultaneously, to receive some (or all) of the total tailings production.

With open cut mines it is also not possible to backfill a pit until it is mined out completely, and unless there are some nearby disused underground workings or pits available for backfill, it is generally not possible to dispose of the tailings below ground level at such mines. It is therefore common for open cut mines to have surface tailings disposal facilities.

\section{Surface tailings disposal methods}

For the surface storage of tailings, there are three basic options:

- Conventional dammed storage.

- Robinsky-style thickened tailings storage.

- Dry stacking with filtered tailings.

Conventional dammed storages are by far the most common surface disposal facilities in use, in which a dilute slurry mixture of tailings and water is discharged into an impoundment, typically at concentrations varying between $10 \sim 60 \%$ solids by weight. Such storages are also the source of the vast majority of tailings disasters. This is not to say that all dammed tailings storages have failed or will fail, but they do present a significantly greater risk of an uncontrolled release of huge volumes of tailings than the other two surface storage options, particularly when earthquakes, floods, neglect or complacency enter the scene.

Dry stacking is the least common surface storage method in large scale mining operations, but it is arguably the safest with respect to the uncontrolled release of vast amounts of tailings. However, it requires the highest degree of dewatering of the tailings, typically to contain less than $20 \%$ moisture by weight, which costs more than the other two options. Furthermore, the transport of the relatively dry (soil-like) tailings from the dewatering infrastructure to the storage site generally comes at a greater cost than the other two options, since stacking conveyors or trucks are generally required to transport the tailings.

The Robinsky-style thickened tailings storage method falls between the conventional and dry stacking options. It generally requires the tailings slurry to be dewatered to a higher degree than the conventional dammed storage facilities, typically to around $55^{\sim 70} \%$ by weight. The slurry must remain fluid enough for it to flow as a liquid, not only to enable the tailings transport to take place in a pipeline, but also to enable the tailings to flow away from the end of the pipe under the effect of gravity.

\section{Eli Robinsky's concepts of central thickened discharge and down}

\section{valley discharge}

In the late 1960s a Canadian professor by the name of Eli Robinsky invented the two related tailings storage concepts of Central Thickened Discharge (CTD) and Down Valley Discharge (DVD) (Robinsky, 1975). A CTD is a cone shaped deposit that is formed by discharging thickened tailings slurry from an elevated point above a plane. A DVD is a sloping tailings deposit in a valley that has a relatively small dam at the bottom of the valley. Figures 1 and 2 present aerial photographs of such tailings storage facilities. 


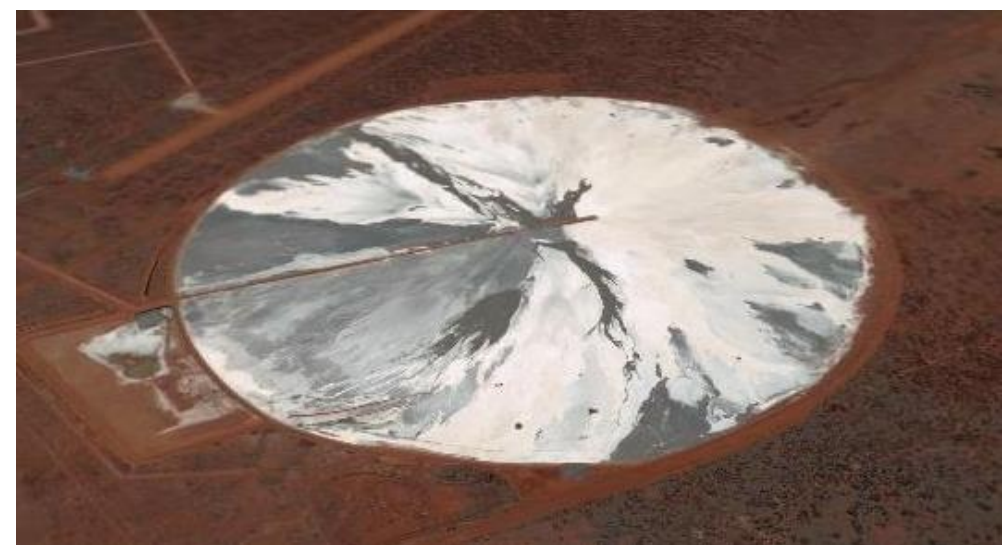

Figure 1 The Sunrise Dam CTD in Australia, operating since 2000 (Note the decant pond to the left)

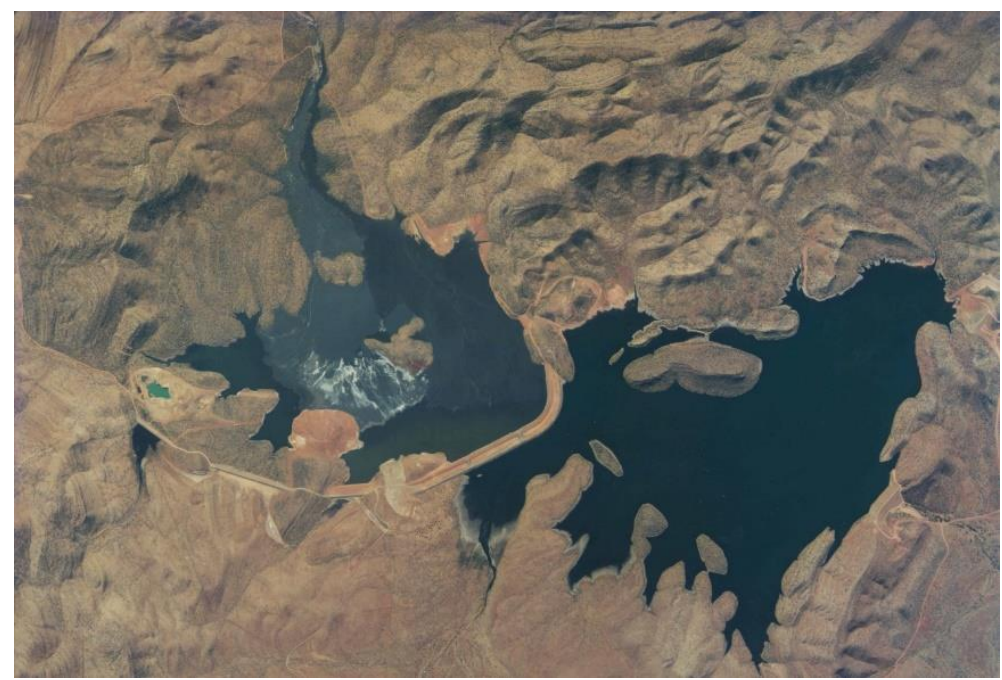

Figure 2 The Century mine DVD in Australia, which started operating in 1999 (Note the decant pond on the right)The curving embankment is a filter dam to retain the tailings but allow water through

Both CTD and DVD concepts exploit the beach slopes that are formed by a thickened tailings slurry upon deposition, enabling embankments to be smaller than would be necessary for a conventional tailings storage facility of equivalent capacity.

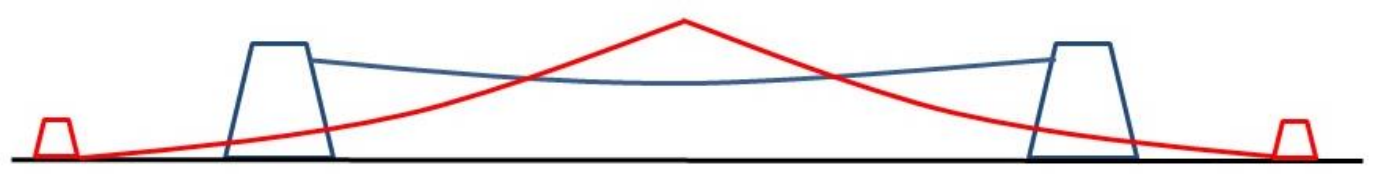

Figure 3 A CTD (red) and a conventional tailings ring dyke (blue) of similar capacity

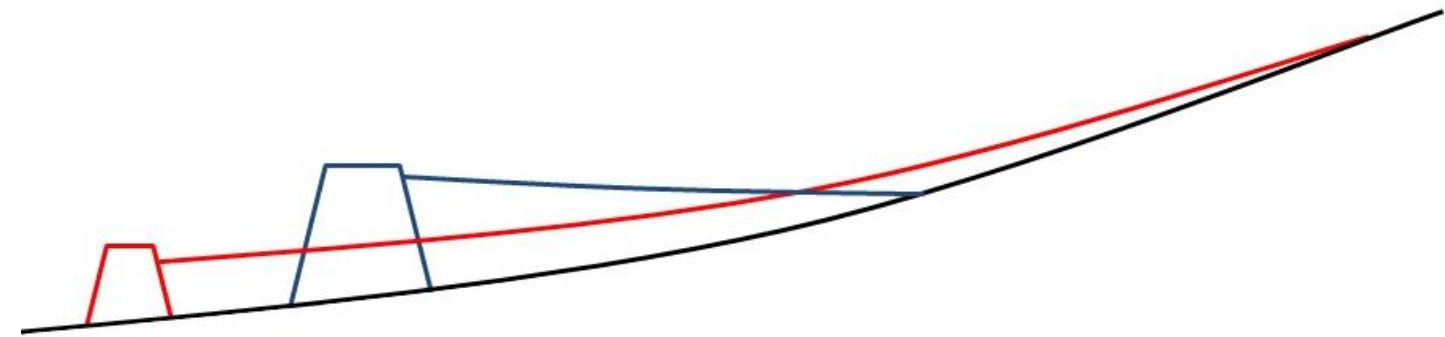

Figure 4 A DVD (red) and a conventional valley dam (blue) of similar capacity 
Figures 3 and 4 show the significant reduction in embankment sizes that can be afforded with the adoption of a Robinsky-style thickened tailings storage facility when compared to a conventional dammed storage of the same tailings storage capacity, but it is noted that these capital cost savings are reduced by the additional cost of the thickeners that are required to increase the slurry concentration beyond its segregation thresholdthe point at which the slurry is able to maintain uniform distribution of fine and coarse particles upon shearing. The pipeline and pumps may also be more expensive for the thickened tailings, although there may be savings in the cost of pumping the return water back to the process plant from the tailings storage facility. Raising of embankments is generally less costly with thickened tailings storages. In some cases it has been found that thickened tailings systems have lower capital costs and lower operating costs than conventional dammed storages, whilst in other cases the opposite can occur (Fitton and Roshdieh, 2012).

A key advantage with the CTD and DVD concepts is the ability to store water in a separate facility, rather than on top of the tailings deposit (as can be seen in Figures 1 and 2). This results in a significant reduction in the amount of water present in the tailings, with most (if not all) of the tailings mass being unsaturated. This in turn enables the tailings to achieve greater strength through the evaporative process of desiccation, whilst greatly reducing (or eliminating in some cases) the driving head that causes seepage of decant water into the ground. A major advantage with the CTD and DVD schemes is that the risk of tailings liquefaction is greatly reduced because the tailings is generally not saturated. The CTD and DVD schemes therefore present a considerably lower risk of uncontrolled release of tailings, compared to a conventional dammed storage.

Other realised benefits of the CTD and DVD concepts are reductions in water losses due to greater recovery from thickeners, and greater access to the tailings surface for capping and rehabilitation.

Most importantly, since the first CTD was established in Canada in 1973, there have not been any catastrophic tailings releases emanating from a CTD or DVD, despite there being over 40 of these thickened tailings storage facilities now established around the world. To those who might suggest that the CTD and DVD technology is so new that it has not yet had much opportunity for failures to occur, it is worth pointing out that the Mount Polley TSF was built in 1995, and the Samarco dam was built in 2008, both more recent than the construction of many of the Robinsky-style tailings facilities.

\section{Relative disposal cost of alternative surface tailings disposal}

\section{methods}

Some effort is made here to illustrate the relative costs of the main surface tailings disposal methods.

There are a number of different dewatering technologies available for recovering the water from tailings slurry, each of which has its own capital cost and operating expense. However, in the selection of a dewatering technology for a given mining operation, the downstream requirements for each must also be considered in order to determine the optimum economic solution. The dewatering method dictates the type of storage that must be designed for the tailings. The topographic conditions at the mine can force the most economic storage site to be a considerable distance away. The selection of a storage site in turn dictates the transport costs for sending the tailings there and bringing any water back. The climatic conditions at the mine also have a significant impact on the evaluation of the make-up water requirements of a tailings system, so it is essential that a water balance is prepared for each possible tailings storage. Finally, the cost of make-up water has the greatest impact on the outcome in such studies, with electricity supply costs also being of importance.

As an example of this, a trade-off study for a large copper mine investigated the use of high rate thickeners, high density thickeners, paste thickeners and filter presses as dewatering alternatives. For each of these dewatering options, a different tailings storage facility was designed, with transport infrastructure designed 
to suit. The overall results of the study are presented in Figure 5:

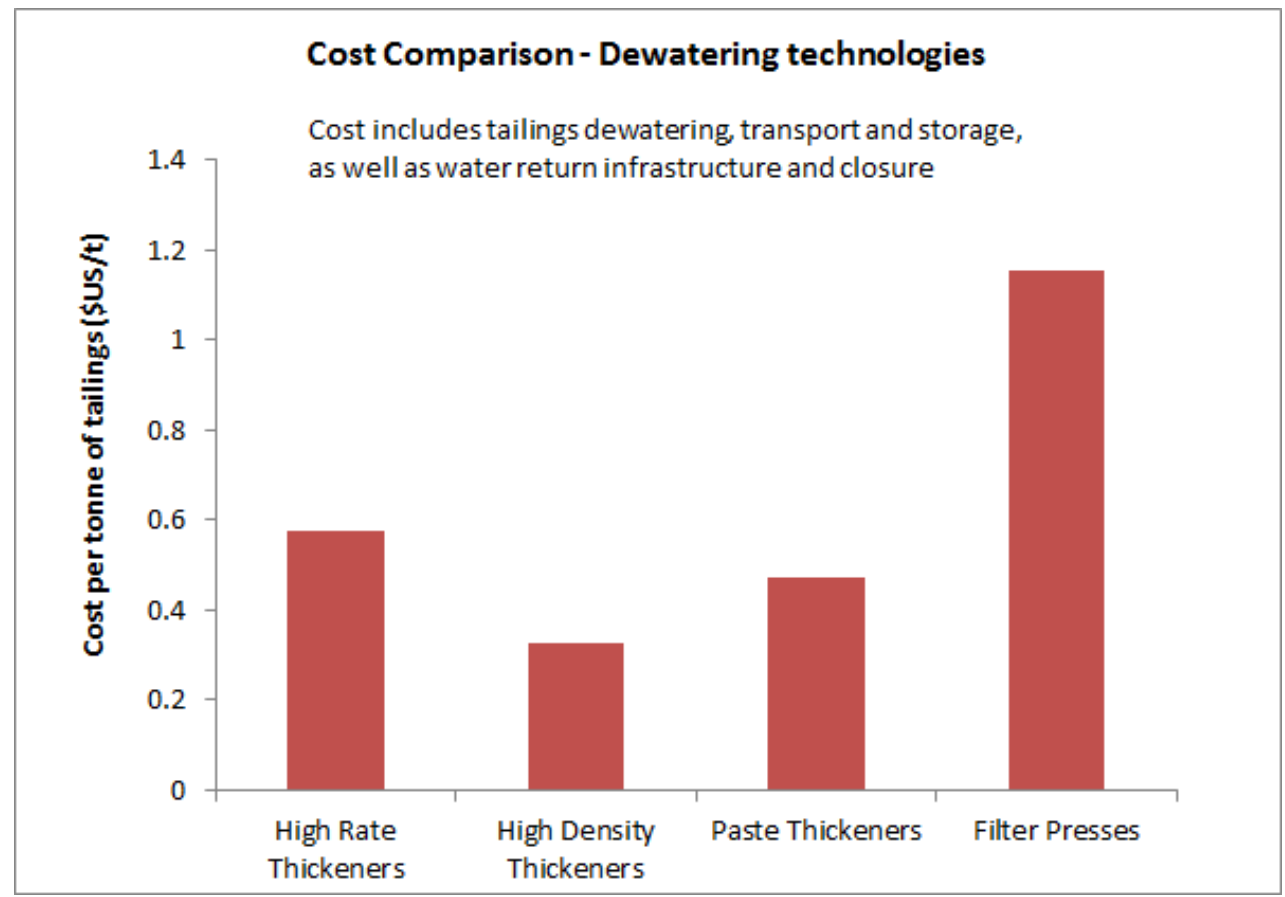

Figure 5 Comparative costs of tailings dewatering alternatives for a large copper mine (Fitton, 2013)

In the particular scenario presented in Figure 5, the high rate thickeners were not able to thicken the slurry sufficiently to exceed the segregation threshold, so this option required a conventional dammed storage. The cost of the embankments caused the total cost of this option to be higher than the other two thickener options. The high density and paste thickeners were both able to create a non-segregating underflow, but the rheological properties of the paste thickener underflow made it a more expensive slurry to transport. The filtration option was more expensive than the three thickener options, not only because of the high operating costs, but also because of the high cost of transportation of the filter cake. In this study the high density thickener option featured a CTD type tailings storage facility, and it was found to yield the greatest economy overall. It must be noted, however, that in some other tailings trade-off studies, the thickened tailings option has not always worked out to being the cheapest (Fitton and Roshdieh, 2012). Nevertheless, its advantages, particularly relating to social and environmental risk, should not be overlooked.

\section{$5 \quad$ Tailings beach slope}

Despite more than 40 years of use in the mining industry, the Robinsky-style thickened tailings storage concepts have not been as widely adopted as they deserve. To a large degree, this poor reception of the technology has been due to a few instances of failure to achieve the expected tailings beach slope-a key parameter in the design of such a storage facility. An example of this occurred at the Esperanza copper mine in Chile (Gaete and Bello, 2013) due to an inability to achieve the targeted underflow density from the thickener, which caused unexpected costs and delays to the mining operation.

In North America, where Robinsky conceived his idea of thickened discharge, and indeed where the first CTD was designed by him, then built and successfully operated for several decades, the technology has sadly not caught on beyond the first example at Kidd Creek. It is believed that Robinsky's second attempt to implement a CTD in Canada in the early 1980s met with a similar outcome to the Esperanza project, where the planned beach slopes were not achieved, and the project was unsuccessful. Recent attendance at a tailings conference in North America led the author to meet several tailings design engineers who hold the belief that thickened discharge "doesn't work" (Anon, 2016). 
China's attitude towards the technology appears to be only slightly better, with comments from their leading researchers such as "it needs more work" (Wu, 2016).

Even in Australia, where more than a dozen thicken tailings schemes have been built and operated successfully over the past 35 years, there remains a lack of faith in the ability to reliably design a thickened tailings storage (Jewell, 2012).

The reasons for this lack of faith stem from three main problems:

- Poor prediction of beach slope.

- Unrealistic expectation of thickener performance.

- Closed mindedness and ignorance within the industry, despite numerous successes.

In reality, the ability to predict tailings beach slopes has improved significantly during the past 10 years, with numerous mathematical models developed and published to enable a reasonably accurate prediction to be made (Fitton, 2007; Simms et al., 2011; Fitton and Slatter, 2013; McPhail, 2014; Fitton, 2014; Pirouz et al., 2014; Quelopana, 2015; Fitton, 2016b). However, in the early days of thickened tailings design, many engineers relied on small scale depositional flume tests, in which a limited quantity of tailings was discharged into a fish tank (or similar vessel) to form a deposit. These small scale slopes were measured and applied to a large scale design without any scientific basis. Experience has proven this 'fish tank flume' approach to be invalid as a method of predicting beach slopes (Fitton, 2007).

The issue of unrealistic expectation of thickener performance still remains a problem. Many designers continue to adopt very optimistic values of thickener underflow density at the upper end of the values achieved at a pilot scale. Such practice is risky, particularly as it makes no allowance for variability in ore chemistry, grind, throughput and other paras.

Finally, the combination of denial, scepticism and ignorance has slowed the adoption of Robinsky's concepts within the mining industry, despite a growing number of successfully operating facilities in Australia, Africa, the Middle East and South America.

Beyond all of these issues, splitting of flows has enabled beach slopes to be steepened. (Robinsky, 1975; Fitton, 2007; McPhail, 2015; Fitton, 2016a) This technique has already been successfully applied at numerous mines operating thickened tailings storages, and provides some buffer to any inaccuracies in beach slope prediction. This alone reduces much of the perceived risk that has been associated with thickened tailings storage design.

\section{Conclusions}

After more than 40 years of use in the mining industry, the Robinsky-style thickened tailings storage concepts have been well proven. The advantages of the technology are significant when compared to conventional dammed storages, particularly with respect to the risk of dam failure.

This paper aims to make some progress towards enlightening some of the thickened tailings sceptics and newcomers. It also aims to persuade mining companies, engineers and regulators that Robinsky's thickened tailings storage concepts do provide practical, economic and proven alternatives to the conventional tailings dam technology that has left us with so many dam failures over the years.

In China, where the Ministry of Finance has already taken the bold step of promoting underground backfill, it is suggested that consideration should be given to offering similar tax exemptions to miners utilising thickened tailings or dry stacking, since these two technologies can also offer a safer alternative to a conventional tailings dam, particularly where conventional dams would otherwise be used. 


\section{References}

Fitton, T.G. 2007, 'Tailings beach slope prediction ', PhD thesis, RMIT University.

Fitton, T.G. and Roshdieh, A. 2012, 'The impact of slurry rheology on tailings transport and disposal options-Four case studies', Paper Presented at IIR Slurry Pipelines Conference 2012.

Fitton, T.G. 2013, 'Deconstructing dewatering', International Mining, June 2013 Supplement-Paste Tailings Management, Australian Centre for Geomechanics, Perth.

Fitton, T.G. and Slatter, P.T. 2013, 'A tailings beach slope model featuring plug flow', Paper Presented at Paste 2013, Australian Centre for Geomechanics, Perth.

Fitton, T.G. 2014, 'The accuracy of tailings beach slope predictions', Paper Presented at Paste 2014, Australian Centre for Geomechanics, Perth.

Fitton, T.G. 2016a, 'Refining Robinsky-Improving on the Central Thickened Discharge Concept', Paper Presented at Tailings and Mine Waste 2016.

Fitton, T.G. 2016b, 'Fitton-Tailings beach slope model incorporating some hydraulic advances', Paper Presented at Paste 2016, Gecamin, Santiago.

Fourie, A.B. 2012, 'Perceived and realised benefits of paste and thickened tailings for surface deposition', Paper Presented to Paste 2012, Australian Centre for Geomechanics, Perth.

Gaete, S. and Bello, F. 2013, 'Experience with the thickening and discharge of high density tailings: Minera Esperanza', Paper Presented to Tailings 2013.

Jewell, R.J. 2012, 'Putting beach slope prediction into perspective', Journal of The Southern African Institute of Mining and Metallurgy, Vol 112(11), pp. 927-932.

McPhail, G. 2014, 'Using small scale flumes to determine rheology at low shear rates', Tailings 2014.

Pirouz, B., Javadi, S., Seddon, K.D., and Williams, M.P.A. 2014, 'Modified beach slope prediction model for non-segregating thickened tailings', Paper Presented at Paste 2014, Australian Centre for Geomechanics, Perth.

Quelopana, H. 2015, 'Tailings Beach Slope Forecasting: What does the data reveal?', Paper Presented to Tailings 2015.

Robinsky, E.I. 1975, 'Thickened discharge-A new approach to tailings disposal', CIM Bulletin, vol. 68, pp. 47-53.

Simms, P., Williams, M.P.A., Fitton, T.G. and McPhail, G. 2011, 'Beaching angles and evolution of stack geometry for thickened tailings: A review', Paste 2011, Australian Centre for Geomechanics, Perth.

Williams, M.P.A., Seddon, K.D, and Fitton, T.G. 2008, 'Surface Disposal of Paste and Thickened Tailings-a brief history and current confronting issues', Paper Presented to Paste 2008, Australian Centre for Geomechanics, Perth.

Wu, A.X. 2016, 'Paste and Thickened Tailings operations and research in China', Australian Centre for Geomechanics. 